\title{
人体微生物群和胰腺癌的相关性研究
}

\author{
李晓东 ${ }^{1,2 \dagger^{*}}$, 间昕琪 ${ }^{1,2 \dagger}$, 刘丕旭 ${ }^{1,3^{*}}$
}

1. 大连医科大学肿瘤干细胞研究院, 大连 116044;

2. 大连医科大学大学生创新创业指导中心, 大连 116044;

3. 大连医科大学药学院, 大连 116044

†同等贡献

*联系人, E-mail: xd_li201212@dmu.edu.cn; pixu_liu@dmu.edu.cn

收稿日期: 2021-10-22; 接受日期: 2021-11-15; 网络版发表日期: 2021-12-13

辽宁省自然科学基金(批准号：2015020670)、辽宁省教育厅基本科研项目(面上项目)(批准号：LJKZ0837)、国家自然科学基金(批准号: 81972482)、辽宁省重点研发计划(批准号: 2020JH2/10300049)和辽宁省“兴辽英才计划”(批准号: XLYC2002043)资助

摘要胰腺癌的恶性程度很高, 目前对其诊断和治疗都缺乏相应方法, 其发病率和死亡率近年来明显增高, 并且 生存率低, 5 年生存率 $<1 \%$, 预后很差. 由于确诊困难, 早期确诊率低, 如能找到一种早期临床诊断胰腺癌的方法, 将会极大改善胰腺癌患者术后的预后情况. 胰腺癌有很多常见的危险因素, 如慢性胰腺炎、糖尿病、高脂饮食、 肥胖、肠道生态失调等. 20 世纪90年代, 人们在对胃癌的发病原因进行研究发现, 幽门螺杆菌是引起胃癌的致病 因子，由此为人们提供了研究肿瘤发病的新方向——微生物群与肿瘤发病的相关性。越来越多的研究结果表明， 胰腺癌的发病与人体内微生物菌群的变化有关. 本文主要就目前人体微生物群与胰腺癌相关性的研究现状, 探究 人体微生物群和胰腺癌发病的相关性, 旨在找到人体微生物群在胰腺癌发病过程中的变化及作用机制, 从而探索 新的胰腺癌诊断和治疗方法.

关键词胰腺癌, 人体微生物群, 胰腺癌诊断与治疗方法

近年来，胰腺癌的诊断与治疗逐渐受到人们的关 注. 2020 年宋春花等人 ${ }^{[1]}$ 通过患者主观整体评估 $(\mathrm{Pa}-$ tient-Generated Subjective Global Assessment, PGSGA), 评价了国内住院的几种常见恶性肿瘤患者的营 养状况. 结果显示, 胰腺癌患者的PG-SGA得分最高, 表明胰腺癌的重度营养不良发生率最高, 胰腺癌患者 的预后较差. 因此, 亟需探索新的研究方向来解决胰 腺癌诊断、治疗的难题. 随着微生物群与癌症的联系 从研究中得到证实，越来越多的研究人员开始关注人
体微生物群与胰腺癌的联系.

人体微生物群是指生活在正常人体体表及与外界 相通的腔道中的微生物群落, 主要包括细菌、真菌、

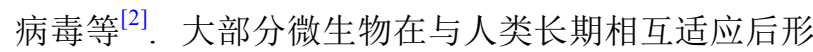
成共生关系，处于动态平衡中，协助人体正常生理功 能, 并与人体健康密切相关. 然而, 这种平衡一旦被打 破, 就容易引发一系列疾病, 甚至导致癌症. 越来越多 的研究表明, 胰腺癌与人体微生物群中的细菌、真 菌、病毒有明显的相关性 ${ }^{[3]}$. 
2019年, Sethi等人 ${ }^{[4]}$ 对微生物在免疫治疗方面的 作用进行了归纳总结, 阐述了胰腺癌可由炎症驱动, 如肥胖、2型糖尿病、胰腺炎、脂多糖、下游炎症通 路(如NF-אB, IL6, STAT3的上调)等, 这些炎症可以将 具有致癌Kras 突变的小鼠早期肿瘤转化为明显的癌 变, 加快癌症的进程. 脂多糖(lipopolysaccharide, LPS) 对Toll样受体(Toll-like receptor, TLR)的刺激也可能与 微生物群与炎症有关. Mai等人 ${ }^{[5]}$ 于2013年对TLR-4在 癌症进展中的作用进行了深入探讨, 认为TLR-4在胰 腺癌发展过程中发挥重要作用. LPS可与模式识别受 体(pattern recognition receptor, PRR)家族成员TLR-4 特异性结合. LPS和TLR-4之间的相互作用可以激活下 游促炎细胞因子的分泌, 将微生物群与炎症联系起来 (图1). 因此, 急性胰腺炎、慢性胰腺炎以及研究指出 的牙周炎都是胰腺癌的危险因素. 2013年, Yadav和 Lowenfels ${ }^{[6]}$ 通过对胰腺炎与胰腺癌的流行病学研究, 发现急性胰腺炎和慢性胰腺炎患者罹患胰腺癌的风险 明显比正常个体增高.

2019年Sethi等人 ${ }^{[4]}$ 的研究认为, 免疫细胞和基质 这两种胰腺肿瘤微环境(tumor microenvironment, TME)的基本组成部分, 共同维持了炎症介导的肿瘤发 生. 早在 2010 年, Erez等人 ${ }^{[7]}$ 针对癌症相关成纤维细胞 (cancer-associated fibroblasts, CAFs)的研究结果表明, 胰腺癌的结缔组织间质诱导促炎细胞因子, 可保护肿 瘤, 使肿瘤不易被机体免疫系统发现. 因此, 免疫治疗 可作为未来胰腺癌的新治疗方向.

此外, 微生物可以影响癌症化疗的疗效和毒性. 2007 年Ozben ${ }^{[8]}$ 提出, 活性氧(reactive oxygen species, ROS)对奥沙利铂作用下的DNA损伤和调亡非常重要. 2013年Iida等人 ${ }^{[9]}$ 的实验表明, 将奥沙利铂用于无菌小 鼠或抗生素处理小鼠, 可以通过下调髓系细胞中ROS 的产生来降低奥沙利铂对肿瘤细胞的毒性. 另外, 吉 西他滨是一种被广泛用于治疗胰腺癌的代表性化疗药 物. 2017 年Geller等人 ${ }^{[10]}$ 的研究显示, 细菌可以利用胞 苷脱氨酶(cytidine deaminase, CDD) 将吉西他滨代谢成 为一种失活形式 ( $2^{\prime}, 2^{\prime}$-二氟脱氧尿苷), 从而使人体对 吉西他滨产生耐药性. Geller等人 ${ }^{[10]}$ 进一步通过对细 菌16S rDNA的深度测序证实, 与胰腺肿瘤相关的微生 物群大多为 $\gamma$-变形菌纲, 包括肠杆菌和假单胞菌属. 2021年, Yu等人 ${ }^{[11]}$ 的研究进一步表明, 这些 $\gamma$-变形菌 纲微生物可产生 CDD, 导致吉西他滨降解和耐药. 可
见肠道菌群可影响化疗药物对胰腺癌的治疗效果.

\section{1 细菌与胰腺癌的相关性研究}

\section{1 肠道菌群与胰腺癌的相关性}

2018年Riquelme等人 ${ }^{[12]}$ 指出, 许多研究表明肠道 菌群可通过调节免疫反应从而影响肿瘤的发展. 同年, Mei等人 ${ }^{[13]}$ 采用 $16 \mathrm{~S}$ rRNA基因焦磷酸测序方法, 分析 胰腺导管腺癌(pancreatic ductal adenocarcinoma, PDAC)患者与健康组体内的微生物群. 结果显示, 与 健康对照组相比, PDAC患者的粪便中有选择性地富 集变形菌门、协同菌门和欧氏菌门细菌.

本文推测, 肠道菌群对肤腺肿瘤的影响可能通过 菌群转移至胰腺, 破坏胰腺正常的微环境或造成炎症, 从而诱发胰腺癌. 比如酒精, 作为胰腺炎常见的致病因 素, 它可以使肠道微生态紊乱, 革兰氏阴性菌过度生 长, 血液中LPS 水平增高, 通过上述机制诱发胰腺 癌 ${ }^{[14]}$. 因此, 可以推断出菌群失调易导致慢性炎症, 而 慢性炎症易诱发胰腺肿瘤.

此外, 肠道菌群可通过调节免疫反应促进肿瘤生 $\mathrm{K}^{[4]}$. 当以缺乏成熟 $\mathrm{T}($ 和 $\mathrm{B})$ 淋巴细胞的 Rag 1 敲除小鼠 进行皮下实验时, 肠道微生物组缺失的肿瘤抑制作用 被消除. 这表明抗生素的减瘤作用不是对癌细胞的脱 靶细胞毒作用, 而是需要适应性免疫的积极参与 ${ }^{[4]}$. 经 典的Th1细胞因子-干扰素 $\gamma($ interferon- $\gamma$, IFN- $\gamma$ )在肿瘤 微环境中发挥抗肿瘤作用, 而Th2/Treg细胞因子-IL-4, IL-5，IL-10等介导促肿瘤作用(图1). 2011年De Monte 等人 ${ }^{[15]}$ 的研究结果显示, TME中Th1:Th2 比值高与胰 腺癌生存期改善相关. 2015 年, Winograd等人 ${ }^{[16]}$ 的研 究显示, 传统的免疫治疗药物, 如免疫检查点抑制剂, 没有对胰腺癌显示出显著的疗效, 部分原因是这种癌 症的效应T细胞浸润最小. 此外, 2018年Sethi等人 ${ }^{[17]}$ 的 研究也证明, 诱导 $\mathrm{T}$ 细胞免疫可以抵消胰腺癌对免疫 检查点抑制剂的耐药性, 在给小鼠口服抗生素后使肠 道微生物消融会导致效应 $\mathrm{T}$ 细胞浸润胰腺肿瘤, 使肿 瘤负荷减小. 因此, 肠道细菌消融能抑制胰腺癌的 发展.

目前也有针对胰腺癌患者胰腺内微环境的相关研 究, 例如, 2019年Leinwand和Miller ${ }^{[18]}$ 试图找到胰腺癌 的标志菌群, 这些研究为诊断胰腺癌提供了新方向.

(1) 幽门螺杆菌与胰腺癌的相关性. 幽门螺杆菌早 


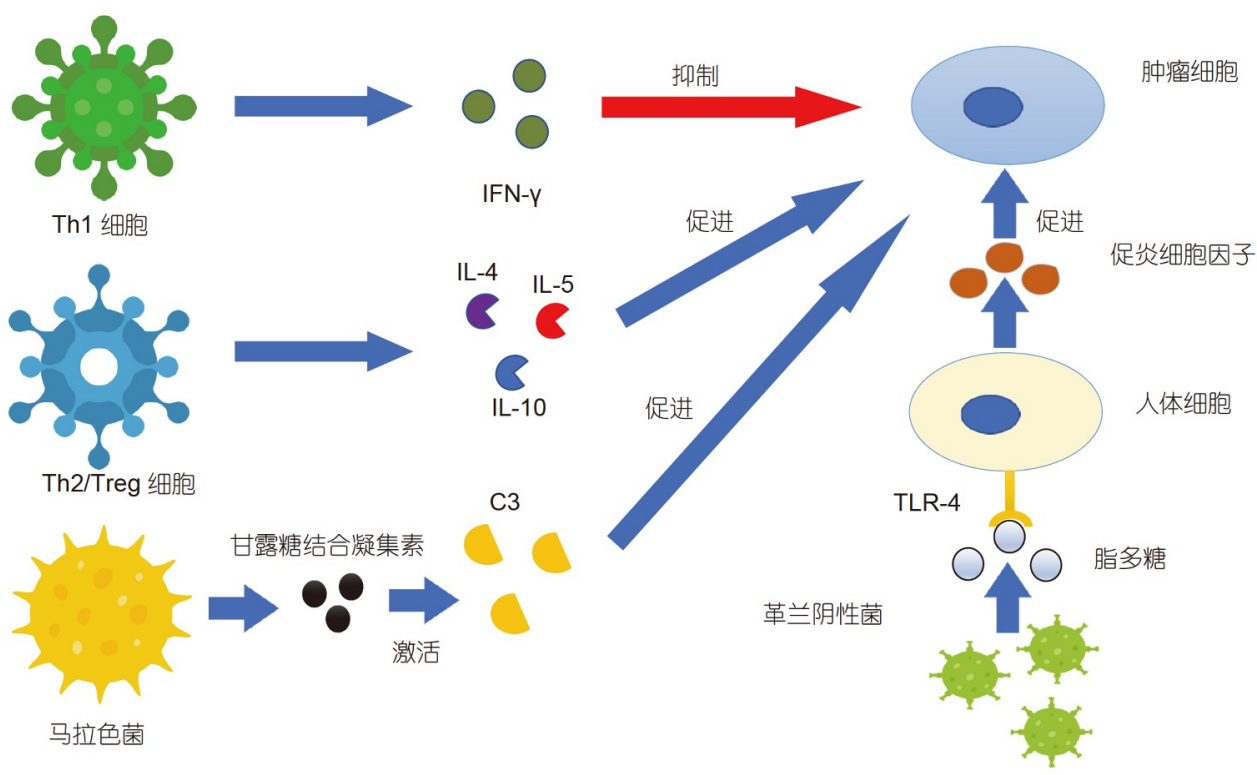

图 1 人体微生物对肿瘤的影响

Figure 1 Effects of human microorganisms on tumors

在20世纪便被发现与胃癌有关. 1996年, Theyer等人 ${ }^{[19]}$ 系统阐述了幽门螺杆菌与胰腺癌的发病有一定的关 联. 幽门螺杆菌是一种微需氧的革兰氏阴性菌, 主要寄 生于人体的胃幽门等部位，口腔中也有发现，可致 癌 ${ }^{[20]}$. 2001年，Stolzenberg-Solomon等人 ${ }^{[21]}$ 的对照研 究提示, 胰腺癌患者中幽门螺杆菌感染率较高, 血清 幽门螺杆菌 $\operatorname{IgG}$ 水平也较高. 因此, 幽门螺杆菌被普遍 认为是胰腺癌的致病因素之一，它可能通过引起慢性 黏膜炎症, 改变细胞增殖和分化, 促进胰腺癌的发展.

2019年，肖繁等人关于幽门螺杆菌诱导胰腺癌发 病的机制做出了以下推测: ( i ) 幽门螺杆菌可通过破 坏胃内微环境, 使胃内细菌增多, 从而使强致癌物亚硝 胺的产生增多, 而亚硝胺通过血液运输到胰腺, 从而起 到致癌作用 ${ }^{[22,23]}$. (ii) 幽门螺杆菌感染后通过提高相 关酶的含量使NO增多, 经过一系列化学反应后生成亚 硝酸盐和亚硝基化合物两种强致癌物. 研究显示, 在幽 门螺杆菌感染者体内, 抗坏血酸浓度显著降低(抗坏血 酸是清除亚硝酸盐及亚硝基化合物的物质)，使得胰腺 上皮细胞在致癌物质中发生癌变的概率增高 ${ }^{[23]}$. (iii) 幽门螺杆菌会影响胃内激素分泌，促进上皮细胞释放 炎症介质，引发炎症反应和组织损伤，进而影响胃的 分泌功能. 异常的胃分泌通过刺激胰腺导管上皮细胞, 并在致癌因子的作用下使其发生异常而演变为癌 ${ }^{[23]}$.
以上机制是根据现有研究做出的推测, 幽门螺杆菌引 发胰腺癌的具体机制仍需进一步研究.

（2）伽马变形菌与胰腺癌的相关性. 2017年Geller 等人 ${ }^{[10]}$ 对PDAC患者样本利用实时定量PCR检测细菌 $16 \mathrm{~S}$ 核糖体DNA, 发现大部分PDAC样本中的细菌属于 伽马变形菌纲. 随后进行的实验发现, 伽马变形菌可通 过细菌酶胞苷脱氨酶 $\left(\mathrm{CDD}_{\mathrm{L}}\right)$ 的表达, 将吉西他滨 $\left(2^{\prime}, 2^{\prime}-\right.$ 二氟脱氧胞苷)变为其非活性形式 $2^{\prime}, 2^{\prime}$-二氟脱氧尿苷, 从而调节胰腺肿瘤对吉西他滨的敏感性，造成机体对 吉西他滨的耐药性, 导致胰腺癌的治疗效果欠佳.

（3）铜绿假单胞菌与胰腺癌的相关性. 2016年, Gaida等人 ${ }^{[24]}$ 研究发现, T2R38与胰腺癌侵袭和转移存 在一定联系, 而铜绿假单胞菌的群体感应分子 $\mathrm{N}$-乙酰十二烷基高丝氨酸(N-acetyl-dodecanoyl homoserine, AHL-12)是目前已知的T2R38的唯一天然配体. 本文 推测, 铜绿假单胞菌可通过AHL-12向多种哺乳动物细 胞发出信号, 包括髓样细胞和上皮细胞. 由于其亲脂 性，AHL-12可通过膜自由扩散. 因此，铜绿假单胞菌 与肤腺癌存在一定的相关性.

\section{2 口腔微生物菌群与胰腺癌的相关性}

Farrell等人 ${ }^{[25]}$ 的实验表明, 部分口腔疾病, 如牙周 病，被发现是诱发胰腺癌的因素之一。根据研究发现， 
牙周病可导致炎症, 产生的微生物产物可从口腔扩散 至全身, 从而使口腔菌群移位, 口腔微生态失衡. 2015 年, 由Torres等人 ${ }^{[26]}$ 的实验结果可知, 和健康者相比, 胰腺癌患者的唾液中纤毛菌比例增高, 牙龈卟啉单胞 菌比例降低, 二者比率可考虑用于早期胰腺癌的诊断.

Torres等人的研究表明, 参与牙周病、牙齿脱落启 动的关键病原体与胰腺癌风险增加有关. 牙龁卟啉单 胞菌、梭杆菌、细长奈瑟菌和米链球菌是参与胰腺癌 发病的口腔细菌中的关键病原体.2012年，Farrell等 人 ${ }^{[25]}$ 针对胰腺癌患者、慢性胰腺炎患者和健康志愿 者进行研究，发现胰腺癌患者的口腔菌群组成与慢性 胰腺炎和健康志愿者有显著区别，表明特定的细菌可 能与胰腺癌的发病有关. 这为未来通过口腔微生物菌 群的特征进行胰腺癌的预警和诊断提供了希望.

(1) 口腔幽门螺杆菌与胰腺癌的相关性. 1989年 Shames等人 ${ }^{[27]}$ 第一次在胃炎患者的口腔中分离出幽 门螺杆菌, 研究提示口腔可能是幽门螺杆菌感染的主 要区域之一.

(2) 牙龁卟啉单胞菌与胰腺癌的相关性. 牙龈卟啉 单胞菌是一种导致慢性牙周炎的致病菌. 随着研究深 入, 人们发现它与肤腺癌有密切联系 ${ }^{[28]}$.

2012年Michaud等人 ${ }^{[28]}$ 测量了 405 例胰腺癌患者 和416例匹配对照的诊断前血液样本中口腔细菌的抗 体, 排除相关影响因素后, 结果显示患有牙周病的男性 患胰腺癌的风险更大. 此外, 牙龈卟啉单胞菌在牙周病 患者口腔中的丰度明显上升 ${ }^{[26]}$. 牙龁卟啉单胞菌抗体 水平高的个体患胰腺癌的风险比抗体水平低的个体高 出两倍. 因此, 这提示牙龈卟啉单胞菌与胰腺癌的发病 有关.

本文对牙龈吓啉单胞菌影响肤腺癌发病率有以下 几种猜测: （ｉ）假设牙龈卟啉单胞菌在炎症引发中发 挥关键作用, 有研究支持牙周病患者口腔内牙龈卟啉 单胞菌的LPS和TLRs发生相关的免疫应答从而促进胰 腺癌进展 ${ }^{[29]}$; (ii) 假设一个潜在的机制可能是, 牙龈卟 啉单胞菌分泌的一种肽基精氨酸脱亚胺酶导致精氨酸 降解后引起 $\mathrm{p} 53$ 和K-ras突变, 从而增加胰腺癌的风 险 ${ }^{[11]}$. 大约有 $50 \%$ 的胰腺癌患者体内存在 $\mathrm{p} 53$ 蛋白突 变. TP53基因是一种典型的抑癌基因, 其表达的P53蛋 白在突变后会失去原有的抑癌功能, 通常会获得新的 致癌功能 ${ }^{[30]}$.

(3) 其他菌群与胰腺癌的相关性. Farrell等人 ${ }^{[25]}$ 的
研究表明, 口腔中其他细菌同样可能引发胰腺癌. 他们 对胰腺癌患者的唾液样本进行研究, 发现部分菌群与 正常对照相比有明显区别, 其中长型奈瑟菌和轻型链 球菌的丰度降低, 毗邻颗粒链球菌的丰度增加. 轻型 链球菌有一定的抑制牙周炎的作用，丰度减少可能会 引发牙周炎; 同时毗邻颗粒链球菌可能会引发人体炎 症, 进而增加人体䍜患胰腺癌的风险. 他们还发现, 在 对胰腺癌患者和健康受试者进行实验时, 延长芽胞杆 菌和米氏葡萄球菌生物标记物的组合具有很高的敏感 性和特异性 ${ }^{[25]}$.

\section{2 真菌与胰腺癌的相关性研究}

真菌作为人体微生物的一部分, 栖息在肠道、口 腔等黏膜处，可在机体受到损伤时激活炎症过程. 2019年Dambuza和Brown ${ }^{[31]}$ 发现，真菌可通过小鼠胰 管从肠道转移到胰腺.

此外, Aykut等人 ${ }^{[32]}$ 利用DNA测序, 在癌变胰腺中 寻找真菌特异性基因组标记. 获得结果与正常组相比, 患有胰腺癌的患者体内胰腺真菌定植增加. 研究人员 发现, 胰腺里的马拉色菌对胰腺癌肿瘤有医学意义. 马拉色菌是常见的一种哺乳动物皮肤上的真菌. Aykut 等人随后通过实验发现, 抗真菌药物阻止了小鼠的 PDAC进展, 并提高了化疗疗效, 随后用马拉色菌对已 抗真菌处理的动物种群进行再次处理加速了PDAC的 生长. 研究者对马拉色菌如何促进PDAC的进展进行 了深入研究, 通过基因表达分析显示, 人类PDAC的存 活率与甘露糖结合凝集素(mannose-binding lectin, MBL)分子的表达有关. MBL是肝脏产生的一种可溶 性蛋白质, 它与微生物表面的碳水化合物结合, 然后 激活血液中称为补体级联的蛋白质系统. 补体级联具 有多种免疫功能, 包括激活免疫细胞来摄取和杀死真 菌及其他病原体. 这种级联反应还与肿瘤的发展有关, 因为它的促炎途径刺激细胞(包括癌细胞)的生长、生 存和运动. MBL可激活血液中的 $\mathrm{C} 3$ 补体级联, 发挥免 疫功能从而促进肿瘤细胞的增殖. 最后一组实验中, Aykut等人 ${ }^{[32]}$ 发现, 在缺乏MBL或补体级联关键成分 $\mathrm{C} 3$ 的小鼠中, 即使在胰腺中存在马拉氏菌, PDAC进展 也会延迟. 因此, 马拉色菌是通过补体级联来促进胰腺 炎症, 从而增强PDAC的进展(图1).

Aykut等人 ${ }^{[32]}$ 的研究显示, 服用了两性霉素B消融 
真菌的 $\mathrm{KC}$ 小鼠增强了基于吉西他滨的化疗效果，同 时, 氟康唑也有效果. 综上, 特定种类真菌可促进胰腺 肿瘤。胰腺真菌群需要 MBL-C3 轴促进肿瘤生长 (KRAS诱导炎症一激活MBL-C3 一促进胰腺肿瘤).

值得注意的是，由于肠道真菌比细菌更容易受到 组成变化的影响, 因此人们推测细菌微生物群的破坏 是真菌过度生长的先决条件.

\section{3 病毒与胰腺癌的相关性研究}

大量研究证明 $\mathrm{HBV} / \mathrm{HCV}$ 与肝癌之间存在联系, 但 其与胰腺癌的联系最近几年才受到重视. 2013年Xing 等人 ${ }^{[33]}$ 对 $\mathrm{HBV} / \mathrm{HCV}$ 与胰腺癌的关系进行研究, 发现 $\mathrm{HBV}$ 或HCV感染可能会增加胰腺癌的发病风险. 同时 $\mathrm{Xu}$ 等人 ${ }^{[34]}$ 进行的另一项荟萃分析结果表明, 慢性HBV 和HCV感染可能会导致胰腺癌发病风险明显增加. 该 项研究结果表明, 感染过HBV, 尤其是免疫力较差的 人群, 有更高的胰腺癌患病风险.

2005年Katakura等人 ${ }^{[35]}$ 发现病毒性肝炎患者的血 清胰酶水平升高，而2013年Jin等人 ${ }^{[36]}$ 发现乙肝病毒与 慢性胰腺炎之间存在联系。这些研究将慢性肝炎、慢 性肤腺炎和胰腺癌联系起来，并证明了病毒在胰腺癌 中的潜在作用不可忽视.

2020 年Tassone等人 ${ }^{[37]}$ 针对溶瘤病毒(oncolytic viruses, OVs)的治疗进行了阐述, 介绍了这一方法目前 的进展及前景. 溶瘤病毒治疗PDAC的最大阻碍是促 结缔组织增生和免疫抑制胰腺TME. TME限制了治疗 药物的获得以及效应 $\mathrm{T}$ 细胞和自然杀伤细胞对肿瘤细 胞的抑制作用 ${ }^{[38]}$. 此外, Tassone等人 ${ }^{[37]}$ 提出癌细胞促 进免疫抑制因子的分泌，进而形成逃避宿主免疫系统 的机制. 由于OVs具有溶瘤和免疫刺激的特性，因此 OVs是对抗免疫抑制胰腺TME和设计联合治疗方案的 理想候选, 可用于临床试验以改善PDAC的预后.

\section{4 胰腺癌的微生物诊断与治疗}

目前仍缺少有效辨别早期胰腺癌的诊断方法. 科 学家们针对人体微生物组与胰腺癌的研究进行了以下 猜测.

胰腺癌患者胰腺中的细菌特征可作为生物标记或 预测因子. 2019年Riquelme等人 ${ }^{[39]}$ 利用16S rRNA基因
测序分析短期生存期和长期生存期的PDAC患者的肿 瘤微生物组组成. 他们支持假黄单胞菌-链霉菌-糖多 孢菌-克劳氏芽孢杆菌能高度预测患者的长期生存率.

在治疗方面, 目前胰腺癌的最佳治疗方式仍为手 术切除，但其切除后复发率高，所以对于可切除的胰 腺癌, 一般采用手术切除联合化疗. 吉西他滨是一种 常用的胰腺癌化疗药物, 可单独使用或与其他药物, 如白蛋白结合紫杉醇、叶酸(亚叶酸钙)、5-氟尿嘧 啶、奥沙利铂和伊立替康联合使用.

2017年Geller等人 ${ }^{[10]}$ 研究发现, 伽马变形菌纲具 有通过 $\mathrm{CDD}_{\mathrm{L}}$ 将吉西他滨代谢为非活性代谢物的能力, 使机体产生耐药性. 因此人体微生物可通过影响人体 对药物的耐药性，影响胰腺癌的进展. 2018年Mei等 人 $^{[13]}$ 研究发现, 抗生素的使用逆转了这一效果. 此外, 科学家们还提出了以下 6 种未来胰腺癌的治疗方法.

(1) 可通过修改肠道微生物群, 从而抑制肿瘤的生 长 $^{[40]}$. 比如通过粪便微生物群的移植, 改善肠道微生 物群，或使用益生素和益生元来恢复正常肠道微生物 群的平衡 ${ }^{[41]}$, 降低微生物遗传毒性和促肿瘤代谢产物, 抑制致癌信号通路. 调节肠道微生物也可影响肿瘤对 化疗药物的敏感性 ${ }^{[10]}$.

(2) 可通过控制真菌感染的MBL来抑制肿瘤 ${ }^{[32]}$. MBL可以识别真菌病原体并激活补体级联蛋白的凝 集素途径. 根据癌症基因组图谱(The Cancer Genome Atlas, TCGA)的转录组数据, MBL(也称为MBL2)的表 达与PDAC患者的生存率降低有关. 2019年Aykut等 人 $^{[32]}$ 推测真菌可能通过激活MBL促进肿瘤的发生. 因 此这也是一种胰腺癌治疗的新方向.

(3) 可通过使用抗真菌的两性霉素B消融真菌, 进 而阻止肿瘤发展 ${ }^{[32]}$. 2019年Aykut等人 ${ }^{[32]}$ 为了确定真 菌共生失调对PDAC进展的影响，在 $\mathrm{KC}$ 小鼠模型中采 用口服两性霉素B的方法消融真菌群落. 真菌群的消 融可抑制小鼠癌症的进展. 同样，两性霉素B在PDAC 侵袭性原位模型中对肿瘤进展具有保护作用. 此外, 研 究也发现, 真菌群的消融增强了吉西他滨化疗的效果, 氟康唑治疗也可抑制肿瘤进展.

(4) 可将溶瘤病毒作为一种新兴的治疗途径 ${ }^{[37]}$. 最 近研究报道了一种溶瘤痘苗病毒(vaccinia virus, VV) - VVL $\Delta T K \Delta N 1 L$ ，其具有强大的抗肿瘤活性，并通 过抑制PI $3 \mathrm{~K} \delta$ 的药理作用来增强 $\mathrm{VV}$ 静脉传递, 以防止 巨噬细胞摄取病毒. 在胰腺癌动物模型中，静脉注射 


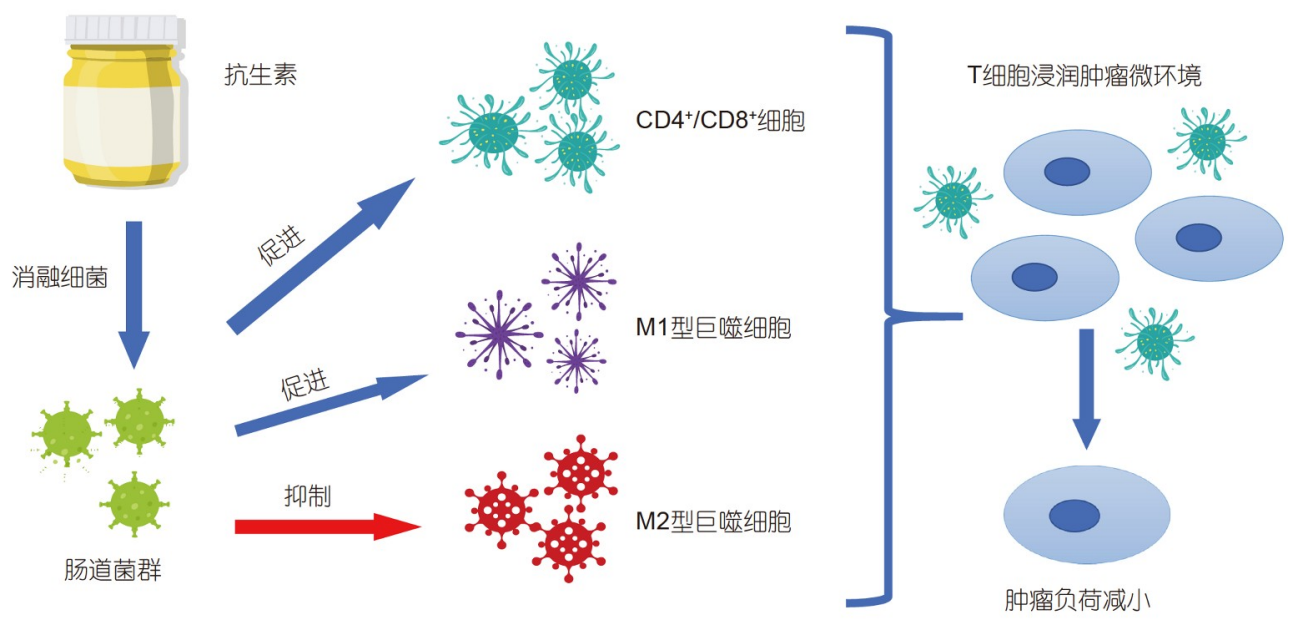

图 2 肠道菌群消融对肿瘤的抑制作用

Figure 2 Inhibitory effects of intestinal microflora ablation on tumors

VVL-21成功地重塑了肿瘤抑制微环境, 促进了抗肿瘤 免疫反应, 提高了长期生存率 ${ }^{[42]}$.

(5) 抗生素治疗作为一个研究热点, 对胰腺癌的作 用具有双面性 ${ }^{[12,43]}$. 2018年Pushalkar等人 ${ }^{[44]}$ 的研究结 果表明，抗生素可增强抗体的抗PD-1作用，使肠道细 菌消融, 并通过上调 T细胞内的PD-1水平, 增强肿瘤内 $\mathrm{CD} 4^{+}$的 $\mathrm{Th} 1$ 极化和 $\mathrm{CD} 8^{+} \mathrm{T}$ 细胞的活化，使 $\mathrm{T}$ 细胞浸润 肿瘤微环境. 同时, 微生物消融使M2型巨噬细胞减少, M1型巨噬细胞数量增加. 针对趋化因子表达的分析表 明, M1相关趋化因子的水平升高, 提高抗原提呈能力, 可使肿瘤负荷减小. 由此可得抗生素对肿瘤有抑制作 用(图2). 但也有研究表明, PDAC患者长期服用抗生素 并不能抑制癌症的发展，抗生素可能会破坏肠道微环 境, 导致抗肿瘤免疫应答受损 ${ }^{[1]}$.

（6）近年来出现了一种新的癌症治疗手段——运 用纳米材料参与癌症免疫治疗 ${ }^{[45]}$. 2021年国内一课题
组还报道了一种载有吉西他滨和免疫检查点抑制剂 anti-PD-L1的肿瘤微环境响应性水凝胶支架, 该支架可 以提高肿瘤微环境的敏感度, 有利于肿瘤免疫治疗 ${ }^{[46]}$.

\section{5 总结}

目前我国胰腺癌的发病率与术后死亡率仍处于上 升状态. 因此, 如果能精确找到人体微生物群与胰腺癌 发生发展的相关性, 就可以对胰腺癌进行有效诊断, 从 而大幅降低肤腺癌术后死亡率. 人们已经发现肠道微 生物、口腔微生物、肠道内部分真菌、病毒等均与胰 腺癌的发生有关. 但其具体的诱导机制仍未研究透彻, 需要深入探索. 未来有望通过检测口腔及胃肠道中的 菌群变化来对胰腺细胞癌变进行诊断及有效预防胰腺 癌的发生发展, 或利用微生物进行免疫治疗, 可有效提 高胰腺癌的治愈率及患病后的存活率.

\section{参考文献}

1 Song C H, Wang K H, Guo Z Q, et al. Investigation of nutritional status in Chinese patients with common cancer (in Chinese). Sci Sin Vitae, 2020, 50: 1437-1452 [宋春花, 王昆华, 郭增清, 等. 中国常见恶性肿瘤患者营养状况调查. 中国科学: 生命科学, 2020, 50: 1437-1452]

2 Guo X K. Human microbiota and microbiome (in Chinese). J Microb Infect, 2017, 12: 132-138 [郭晓奎. 人体微生物群与微生物组. 微生物与 感染, 2017, 12: 132-138]

3 Wang Y, Yang G, You L, et al. Role of the microbiome in occurrence, development and treatment of pancreatic cancer. Mol Cancer, 2019, 18: 173

4 Sethi V, Vitiello G A, Saxena D, et al. The role of the microbiome in immunologic development and its implication for pancreatic cancer immunotherapy. Gastroenterology, 2019, 156: 2097-2115.e2

5 Mai C W, Kang Y B, Pichika M R. Should a Toll-like receptor 4 (TLR-4) agonist or antagonist be designed to treat cancer? TLR-4: its expression 
and effects in the ten most common cancers. Onco Targets Ther, 2013, 6: 1573-1587

6 Yadav D, Lowenfels A B. The epidemiology of pancreatitis and pancreatic cancer. Gastroenterology, 2013, 144: 1252-1261

7 Erez N, Truitt M, Olson P, et al. Cancer-associated fibroblasts are activated in incipient neoplasia to orchestrate tumor-promoting inflammation in an NF-кB-dependent manner. Cancer Cell, 2010, 17: 135-147

8 Ozben T. Oxidative stress and apoptosis: impact on cancer therapy. J Pharm Sci, 2007, 96: 2181-2196

9 Iida N, Dzutsev A, Stewart C A, et al. Commensal bacteria control cancer response to therapy by modulating the tumor microenvironment. Science, 2013, 342: 967-970

10 Geller L T, Barzily-Rokni M, Danino T, et al. Potential role of intratumor bacteria in mediating tumor resistance to the chemotherapeutic drug gemcitabine. Science, 2017, 357: 1156-1160

11 Yu Q, Jobin C, Thomas R M. Implications of the microbiome in the development and treatment of pancreatic cancer: thinking outside of the box by looking inside the gut. Neoplasia, 2021, 23: 246-256

12 Riquelme E, Maitra A, McAllister F. Immunotherapy for pancreatic cancer: more than just a gut feeling. Cancer Discov, 2018, 8: 386-388

13 Mei Q X, Huang C L, Luo S Z, et al. Characterization of the duodenal bacterial microbiota in patients with pancreatic head cancer vs. healthy controls. Pancreatology, 2018, 18: 438-445

14 Pang B Y, Jiang Y F, Li Y, et al. Research progress on the relationship between intestinal flora and extra-intestinal tumors (in Chinese). J Pract Med, 2017, 33: 3488-3491 [庞冰玉, 姜雅菲, 李颖, 等. 肠道菌群与肠道外肿瘤关系的研究进展. 实用医学杂志, 2017, 33: 3488-3491]

15 De Monte L, Reni M, Tassi E, et al. Intratumor T helper type 2 cell infiltrate correlates with cancer-associated fibroblast thymic stromal lymphopoietin production and reduced survival in pancreatic cancer. J Exp Med, 2011, 208: 469-478

16 Winograd R, Byrne K T, Evans R A, et al. Induction of T-cell immunity overcomes complete resistance to PD-1 and CTLA-4 blockade and improves survival in pancreatic carcinoma. Cancer Immunol Res, 2015, 3: 399-411

17 Sethi V, Kurtom S, Tarique M, et al. Gut microbiota promotes tumor growth in mice by modulating immune response. Gastroenterology, 2018, 155: $33-37 . e 6$

18 Leinwand J C, Miller G. Microbes as biomarkers and targets in pancreatic cancer. Nat Rev Clin Oncol, 2019, 16: 665-666

19 Theyer U, Wrba F, Kornek G, et al. 151 O Association between Helicobacter pylori infection and pancreatic cancer. Eur J Cancer, 1996 , 32 : S29

20 Engstrand L, Lindberg M. Helicobacter pylori and the gastric microbiota. Best Pract Res Clin Gastroenterol, 2013, 27: 39-45

21 Stolzenberg-Solomon R Z, Blaser M J, Limburg P J, et al. Helicobacter pylori seropositivity as a risk factor for pancreatic cancer. J Natl Cancer Inst, 2001, 93: 937-941

22 Capurso G, Delle Fave G, Lemoine N. Re: Etiology of pancreatic cancer, with a hypothesis concerning the role of $N$-nitroso compounds and excess gastric acidity. J Natl Cancer Inst, 2004, 96: 75; author reply 75-6

23 Xiao F, Guo X Y, Wang G, et al. Research status and development of digestive system microecology and pancreatic cancer (in Chinese). Chin J Dig Surg, 2019, 18: 1001-1004 [肖繁, 郭笑宇, 王刚, 等. 消化系统微生态与胰腺癌的研究现状和发展. 中华消化外科杂志, 2019, 18: 10011004]

24 Gaida M M, Mayer C, Dapunt U, et al. Expression of the bitter receptor T2R38 in pancreatic cancer: localization in lipid droplets and activation by a bacteria-derived quorum-sensing molecule. Oncotarget, 2016, 7: 12623-12632

25 Farrell J J, Zhang L, Zhou H, et al. Variations of oral microbiota are associated with pancreatic diseases including pancreatic cancer. Gut, 2012, 61: $582-588$

26 Torres P J, Fletcher E M, Gibbons S M, et al. Characterization of the salivary microbiome in patients with pancreatic cancer. PeerJ, 2015, 3: e1373

27 Shames B, Krajden S, Fuksa M, et al. Evidence for the occurrence of the same strain of Campylobacter pylori in the stomach and dental plaque. J Clin Microbiol, 1989, 27: 2849-2850

28 Michaud D S, Izard J, Wilhelm-Benartzi C S, et al. Plasma antibodies to oral bacteria and risk of pancreatic cancer in a large European prospective cohort study. Gut, 2012, 62: 1764-1770

29 Zhao S Y, Zhu K X, Li W J. Study advances of microorganisms and pathogenic mechanism of pancreatic cancer (in Chinese). Chin J Bases Clin Gen Surg, 2020, 27: 1044-1048 [赵素月, 朱克祥, 李文军. 微生物与胰腺癌致病机制研究进展. 中国普外基础与临床杂志, 2020, 27: 1044$1048]$

30 Wang F, Hou Y S, Yang D. Molecular evolutionary mechanisms underlying tumorigenesis, tumor development, and metastasis (in Chinese). Sci 
Sin Vitae, 2020, 50: 1418-1426 [王斐, 侯雨杉, 杨冬. 肿瘤发生发展和转移过程中的分子进化机制. 中国科学: 生命科学, 2020, 50: 14181426]

31 Dambuza I M, Brown G D. Fungi accelerate pancreatic cancer. Nature, 2019, 574: 184-185

32 Aykut B, Pushalkar S, Chen R, et al. The fungal mycobiome promotes pancreatic oncogenesis via activation of MBL. Nature, 2019, 574: 264-267

33 Xing S, Li Z W, Tian Y F, et al. Chronic hepatitis virus infection increases the risk of pancreatic cancer: a meta-analysis. Hepatobiliary Pancreat Dis Int, 2013, 12: 575-583

$34 \mathrm{Xu} \mathrm{J} \mathrm{H,} \mathrm{Fu} \mathrm{J} \mathrm{J,} \mathrm{Wang} \mathrm{X} \mathrm{L,} \mathrm{et} \mathrm{al.} \mathrm{Hepatitis} \mathrm{B} \mathrm{or} \mathrm{C} \mathrm{viral} \mathrm{infection} \mathrm{and} \mathrm{risk} \mathrm{of} \mathrm{pancreatic} \mathrm{cancer:} \mathrm{a} \mathrm{meta-analysis} \mathrm{of} \mathrm{observational} \mathrm{studies.} \mathrm{World} \mathrm{J}$ Gastroenterol, 2013, 19: 4234

35 Katakura Y, Yotsuyanagi H, Hashizume K, et al. Pancreatic involvement in chronic viral hepatitis. World J Gastroenterol, 2005, 11: 3508

36 Jin Y, Gao H, Chen H, et al. Identification and impact of hepatitis B virus DNA and antigens in pancreatic cancer tissues and adjacent noncancerous tissues. Cancer Lett, 2013, 335: 447-454

37 Tassone E, Muscolini M, van Montfoort N, et al. Oncolytic virotherapy for pancreatic ductal adenocarcinoma: A glimmer of hope after years of disappointment? Cytokine Growth Factor Rev, 2020, 56: 141-148

38 Feig C, Gopinathan A, Neesse A, et al. The pancreas cancer microenvironment. Clin Cancer Res, 2012, 18: 4266-4276

39 Riquelme E, Zhang Y, Zhang L, et al. Tumor microbiome diversity and composition influence pancreatic cancer outcomes. Cell, 2019, 178: 795806.e12

40 Krishnamoorthy M, Lenehan J G, Burton J P, et al. Immunomodulation in pancreatic cancer. Cancers, 2020, 12 : 3340

41 Shadnoush M, Hosseini R S, Khalilnezhad A, et al. Effects of probiotics on gut microbiota in patients with inflammatory bowel disease: a doubleblind, placebo-controlled clinical trial. Korean J Gastroenterol, 2015, 65: 215

42 Marelli G, Chard Dunmall L S, Yuan M, et al. A systemically deliverable Vaccinia virus with increased capacity for intertumoral and intratumoral spread effectively treats pancreatic cancer. J Immunother Cancer, 2021, 9: e001624

43 Boursi B, Mamtani R, Haynes K, et al. Recurrent antibiotic exposure may promote cancer formation-another step in understanding the role of the human microbiota? Eur J Cancer, 2015, 51: 2655-2664

44 Pushalkar S, Hundeyin M, Daley D, et al. The pancreatic cancer microbiome promotes oncogenesis by induction of innate and adaptive immune suppression. Cancer Discov, 2018, 8: 403-416

45 Hartshorn C M, Bradbury M S, Lanza G M, et al. Nanotechnology strategies to advance outcomes in clinical cancer care. ACS Nano, 2018, 12: $24-43$

46 Fan Q, Wang C. Engineering nanobiomaterials for cancer immunotherapy (in Chinese). Sci Sin Vitae, 2021, 51: 793-803 [范亲, 汪超. 纳米材料 在肿瘤免疫治疗中的应用. 中国科学: 生命科学, 2021, 51: 793-803] 


\title{
Microbiota dysbiosis in pancreatic cancer: evidence of association and tumorigenesis
}

\author{
LI XiaoDong ${ }^{1,2}$, YAN XinQi ${ }^{1,2} \&$ LIU PiXu ${ }^{1,3}$ \\ 1 Institute of Cancer Stem Cell, Dalian Medical University, Dalian 116044, China; \\ 2 Guidance Center for College Students' Innovation and Entrepreneurship, Dalian Medical University, Dalian 116044, China; \\ 3 College of Pharmacy, Dalian Medical University, Dalian 116044, China
}

Pancreatic cancer is a highly malignant disease with poor diagnosis and treatment. Its morbidity and mortality have recently significantly increased with a low survival rate. The 5 -year overall survival rate is less than $1 \%$, and the prognosis is extremely poor. Due to the difficulties and a low rate of early diagnosis, the prognosis of patients with pancreatic cancer after surgery will be greatly improved if early clinical diagnosis of pancreatic cancer is accomplished. There are many common risk factors for pancreatic cancer, such as chronic pancreatitis, diabetes, high-fat diets, obesity, and intestinal disorders. In the 1990s, when the etiology of gastric cancer was studied, Helicobacter pylori was found to be the causative factor of gastric cancer, and the correlation between microbiota and tumor pathogenesis provided a new clue for the study of tumor pathogenesis. Several lines of evidence have shown that pancreatic cancer is highly associated with changes in the human microbiota. Thus, in this paper, we review current evidence on the role of human microbiota in pancreatic cancer development and provide a perspective on the application of microbiota modulation in the early diagnosis and effective treatment of pancreatic cancer.

pancreatic cancer, human microbiota, pancreatic cancer diagnosis and treatment

doi: $10.1360 /$ SSV-2021-0419 